\title{
Why do wages become more rigid during a recession than during a boom?
}

\author{
Izumi Yokoyama
}

\author{
Correspondence: \\ izumi.yokoyama@r.hit-u.ac.jp \\ Assistant Professor, Department of \\ Economics, Hitotsubashi University, \\ 2-1 Naka, Kunitachi, Tokyo \\ 186-8601, Japan
}

\begin{abstract}
This paper provides a theoretical and empirical analysis of the effect of performance-based layoffs on wage rigidity in the context of performance pay. In the model, it becomes optimal for firms to raise future regular pay to maintain workers' current efforts, which results in downwardly rigid regular pay under the threat of performance-based layoffs. Furthermore, it becomes optimal for firms to base wages less on workers' performance during recessions due to the lower value of productivity. Consequently, wages during recessions also become "rigid" (inflexible) with respect to performance. The Japanese panel dataset supported these theoretical implications.
\end{abstract}

Keywords: Wage rigidity; Performance pay; Performance-based layoffs

JEL codes: J30; J33; J63

\section{Introduction}

When unemployed workers are available, firms do not cut wages until the excess supply is eliminated, which is unexpected in the ideal market scenario depicted by the conventional theory. This phenomenon has puzzled economists, and a number of studies have attempted to understand it. Noteworthy among these studies is the work of Bewley (1999), whose commendable field research provided a clue to the cause of the phenomenon. In his research, Bewley (1999) found that no existing theories on wage rigidity correctly explained his findings in the "real" U.S. labor market, which implied the need for a new theoretical model.

Research on wage rigidity during a recession is important for many reasons, one of which is that wages during a recession can help reduce high unemployment rates. Theoretically, firms could hire more people by paying lower wages to existing workers, and if wages are not decreased during a recession it may prevent new workers from being hired. Thus, if there is a particular reason why wages are not decreased during a recession, it would be worthwhile to understand the possible sources of such wage rigidity.

In this study, I explore the mechanism by which nominal wages become downwardly rigid during a recession (but not during a boom) by showing that firms have reason to resist cutting nominal pay during a recession. I adopted a model in which firms decide the intensity of performance-based layoffs based on market conditions. Consequently,

(c) 2014 Yokoyama; licensee Springer. This is an Open Access article distributed under the terms of the Creative Commons 
in my model, layoffs occur only during recessions. ${ }^{1}$ By adopting this setting, unlike the typical efficiency wage models such as in Shapiro and Stiglitz (1984) and Sparks (1986), wherein an equilibrium with no dismissal is derived, I was able to answer the question: Why do wages not fall during recessions in which firms lay off many workers? $^{2}$

Recently, performance-based pay has been employed in many countries. For example Lemieux et al. (2009) showed that, in the U.S., the proportion of performance-paid jobs is increasing. Moreover, the "pay-for-performance" system has become widespread in many countries since the 1990s. This is particularly so in Japan, where most employees traditionally receive a substantial portion of their pay in the form of bonuses. The amount paid as a bonus generally fluctuates depending on the firm's and the worker's performances. Thus, particularly for countries such as Japan, it is important to assume performance-based pay rather than fixed wages. Given this scenario, the model presented in this study divides a worker's total compensation into two components: a fixed component (regular pay) and a performance-based pay component (bonus). This division makes it possible to determine how each component contributes to wage rigidity during a recession.

According to Bewley (1999), the key reason for a firm's reluctance to cut wages is the belief that nominal wage cuts damage worker morale. This finding implies that, while modeling nominal downward wage rigidity, it might be better to allow wages to positively affect worker performance. The model presented in this study allows interactions between wages and workers' efforts both over and within periods. Since a fixed component and a performance-based pay component play different roles in inducing high levels of effort in a multiple-period model setting, throughout this paper, the different ways that the two components contribute to wage rigidity are explained.

The main results obtained from the theoretical model are as follows: (a) performancebased layoffs are more likely to occur when the layoff costs and the output price are low; (b) regular pay is likely to be downwardly rigid during periods in which performancebased layoffs occur; and (c) bonuses move proportionally to the output price. The rationale behind result (c) is as follows: During a recession, the lower value of productivity discourages firms from maintaining workers' current incentives at high levels, which results in lower bonuses during these periods. As a result, wages during recessions also become "rigid" (inflexible) with respect to performance.

To test the theoretical implications obtained from the model, an empirical analysis is conducted using Japanese panel data from the Keio Household Panel Survey (KHPS), 2004-2007. The empirical part consists of the following two steps: The first step is a layoff regression, which is employed to confirm whether performance-based layoffs are more likely to occur during a recession when the output price is low and for non-union workers whose performance-based layoff costs are relatively low. The second step is a wage regression. This step shows that regular pay becomes downwardly rigid when performance-based layoffs are likely to occur, and that bonuses move proportionally to the output price.

This paper is organized as follows. Section 2 describes the framework of the basic model. Section 3 presents an empirical strategy to test the implications of the theoretical model. Section 4 provides a brief description of the data, and Section 5 discusses the results from the empirical analysis. Section 6 presents the conclusion. 


\section{Basic model}

\subsection{Model structure}

Here, Baily (1977)'s two-period layoff model setting in which layoffs can occur only at the beginning of the second period is adopted. This timing of layoffs divides all periods into two: the period before the timing of the layoff is Period 1, and the period after the timing of the layoff is Period 2. In Section 3, an extended model in which the contract is renewed once the two-period frame is finished is presented.

\subsubsection{Output price}

As assumed in Baily (1977), the firm is a price-taker, and the output price in Period 1 is known to everyone, while the output price in Period 2 is not known in Period 1 and is therefore given as a random variable. The output price for Period 2 is drawn randomly from a distribution, $G(p)$, with a density function of $g(p)>0$ for $p \in\left[p^{-}, p^{+}\right]$and is assumed to be i.i.d. ${ }^{3}$

\subsubsection{Wages}

A worker's wage in each period $i(=1,2)$ is divided into two components; namely, a fixed pay component and a performance-based pay component. The components for each period are expressed as follows:

$$
\begin{aligned}
& w_{1}\left(p_{1}\right)=a_{1}\left(p_{1}\right)+b_{1}\left(p_{1}\right) e_{1} \\
& w_{2}\left(p_{2}\right)=a_{2}\left(p_{2}\right)+b_{2}\left(p_{2}\right) e_{2}
\end{aligned}
$$

where $a$ represents regular (fixed) pay and $b$ represents the "piece rate" paid for each unit of effort, $e$. Both $a$ and $b$ are assumed contingent on the output price, $p_{t}(t=1,2) .{ }^{4}$

\subsubsection{Layoffs}

Here, it is assumed that the firm can decide whether to implement layoffs at the beginning of Period 2, and if a layoff is implemented, it will be a performance-based layoff in which the probability of a worker being laid off is a decreasing function of the effort offered by the same worker in the previous period. As is assumed for wages, the layoff decision is also contingent on the output price. Since the layoff can be implemented at the beginning of Period 2, the layoff decision depends on $p_{2}$.

When the intensity of layoffs given $p_{2}$ is defined as $\gamma\left(p_{2}\right)$, the probability of a worker being retained in the firm can be defined as:

$$
\gamma\left(p_{2}\right) \cdot \min \left(\frac{e_{1}}{\bar{e}}, 1\right)+\left(1-\gamma\left(p_{2}\right)\right) \cdot 1
$$

It is assumed that $\bar{e}$ is given exogenously, while $\gamma$ is chosen by the firm for each realization of $p_{2} \cdot{ }^{5}$ Note that a higher value of $\gamma$ means a worker faces a greater risk of being laid off and that $\gamma=0$ means no layoffs, regardless of the level of the efforts provided in Period 1.

\subsubsection{Timing}

The timing of events is as follows:

1. The output price, $p_{1}$, is observed by every unit in the model.

2. The firm offers a contingent labor contract to potential workers (applicants).

3. Applicants decide whether to accept or reject the firm's offer. If accept, workers exert effort; therefore, production occurs, profits are realized, and payments are made at the end of Period 1. 
4. The output price, $p_{2}$ is realized. At the beginning of Period 2, in the case of $\gamma>0$, workers are laid off with a probability of $\gamma\left(p_{2}\right)\left(1-e_{1} / \bar{e}\right)$. If not laid off, workers who have already worked for one period at the firm and decide to stay in the same firm, enter Period 2.

5. Workers in Period 2 exert effort; therefore, production occurs, profits are realized, and payments are made at the end of Period 2.

6. Workers who have finished their second period at the firm will retire.

\subsection{Workers}

It is assumed that all workers are identical in skill levels and utility functions. It is also assumed that a worker's utility is increasing in wage, $w$, and decreasing in the level of work effort, $e$. Therefore, the posited utility function is:

$$
\text { Utility }=w-\frac{1}{2} e^{2}
$$

Let $V^{E}$ be the discounted expected lifetime utility for a new worker. Assuming that a worker is paid wages at the end of a period, $V^{E}$ is given by:

$$
V^{E}=a_{1}\left(p_{1}\right)+b_{1}\left(p_{1}\right) e_{1}-\frac{1}{2} e_{1}^{2}+\delta \int_{p}\left\{\begin{array}{l}
\left(\gamma(p) \cdot \min \left(\frac{e_{1}}{\bar{e}}, 1\right)+1-\gamma(p)\right) \times \\
\max \left\{a_{2}(p)+b_{2}(p) e_{2}-\frac{1}{2} e_{2}^{2}, U\right\} \\
+\gamma(p)\left(1-\min \left(\frac{e_{1}}{\bar{e}}, 1\right)\right) U
\end{array}\right\} d G(p)
$$

where $U$ is the unemployment insurance benefit for one period, which is exogenously given. ${ }^{6}$ Workers who have completed the first period are allowed to quit the firm if the utility for the second period, calculated based on the output price $p_{2}$, is lower than $U$. Given the contract proposed by the firm, each employed worker decides how much effort to invest in his/her current job to maximize his/her expected lifetime utility. ${ }^{7}$ For $\gamma$ to capture the intensity of performance-based layoffs, it is assumed that the exogenous variable $\bar{e}$ is large enough to ensure that the internal solution for $e_{1}^{*}$ is always less than $\bar{e}$, which results in $e_{1}^{*} / \bar{e}<1$. Then, solving the first-order conditions, the effort supply functions can be written as:

$$
\begin{aligned}
& e_{1}^{*}=b_{1}+\delta E\left[\max \left\{\frac{\gamma(p)}{\bar{e}}\left(a_{2}(p)+b_{2}(p) e_{2}-\frac{1}{2} e_{2}^{2}-U\right), 0\right\}\right] \\
& e_{2}^{*}=b_{2}
\end{aligned}
$$

Eq. (6) and (7) show that workers' current levels of effort depend on the current piece rate, $b$; in other words, $e_{1}^{*}$ and $e_{2}^{*}$ increase in $b_{1}$ and $b_{2}$ respectively. ${ }^{8}$ However, it is more important to note that, as long as a firm pays wages that are higher than those necessary to keep workers during the second period, the effort of a new employee, $e_{1}$, will also be affected by the wages scheduled to be paid in the next period after performance-based layoffs have occurred (i.e., $\gamma(p)>0$ ); that is, in deciding on an optimal level of effort, workers in Period 1 consider the future wage they will receive during periods in which performance-based layoffs occur. This is because, given the possibility of being laid off, workers in Period 1 will receive wages in the second period only if they work hard in the first period and avoid being laid off. Then, higher contingent wages paid in Period 2, in which layoffs occur, encourage workers in Period 1 to work harder.

In contrast, the contingent wages of workers in Period 2, in which layoffs do not occur (i.e., wages with $\gamma(p)=0$ ), do not affect the efforts of workers in Period 1. This is because workers in Period 1 will necessarily receive the wages without being laid off, regardless of 
their current levels of effort. Thus, when $\gamma(p)=0$, only the current piece rate can affect the incentives of workers in Period 1. For example, if layoffs occur only in a recession, wages scheduled to be paid during a recession will affect the levels of effort in Period 1, while wages scheduled to be paid during booms will not.

\subsection{Firms}

Let $C$ be the exogenous costs associated with laying off a worker. The expected profits from hiring a worker at period $t$ can be written as:

$$
\Pi=p_{1} e_{1}-a_{1}\left(p_{1}\right)-b_{1}\left(p_{1}\right) e_{1}+\delta \int_{p}\left\{\begin{array}{l}
\left(\gamma(p) \frac{e_{1}}{\bar{e}}+1-\gamma(p)\right) \\
\times\left(p_{2} e_{2}-a_{2}(p)-b_{2}(p) e_{2}\right) \\
-C \gamma(p)\left(1-\frac{e_{1}}{\bar{e}}\right)
\end{array}\right\} d G(p)
$$

The firm offers a new employee a contingent contract $X=\left(a_{1}\left(p_{1}\right), b_{1}\left(p_{1}\right), \gamma\left(p_{2}\right)\right.$, $\left.a_{2}\left(p_{2}\right), b_{2}\left(p_{2}\right) ; \forall p_{2}\right)$ to maximize profit subject to providing the worker with a competitively determined utility level. Then, the firm's problem can be written as follows:

$$
\begin{aligned}
& \operatorname{Max}_{(X)} \Pi \\
& \text { s.t. }\left\{\begin{array}{l}
V^{E} \geq V^{U} \\
a_{2}\left(p_{2}\right)+b_{2}\left(p_{2}\right) e_{2}-\frac{1}{2} e_{2}^{2} \geq U \quad \forall p_{2} \\
e_{1}^{*}=e\left(b_{1}, \gamma, \bar{e}, a_{2}, b_{2}, U, \delta\right) \\
e_{2}^{*}=e\left(b_{2}\right) \\
\gamma\left(p_{2}\right) \geq 0 \forall p_{2} \\
\gamma\left(p_{2}\right) \leq 1 \quad \forall p_{2}
\end{array}\right.
\end{aligned}
$$

Let $\lambda_{1}\left(p_{2}\right) \geq 0$ and $\lambda_{2}\left(p_{2}\right) \geq 0 \forall p_{2}$ be the Kuhn-Tucker multipliers associated with the participation constraints for a worker in Periods 1 and 2 respectively. $\mu_{1}\left(p_{2}\right) \geq 0$ and $\mu_{2}\left(p_{2}\right) \geq 0 \forall p_{2}$ are the Kuhn-Tucker multipliers associated with $\gamma\left(p_{2}\right) \geq 0$ and $\gamma\left(p_{2}\right) \leq 1 \forall p_{2}$ respectively. Then, the first-order conditions can be solved as follows:

$$
\begin{aligned}
\frac{\partial \mathcal{L}}{\partial a_{1}}= & -1+\lambda_{1}=0 \\
\frac{\partial \mathcal{L}}{\partial b_{1}}= & -e_{1}+\lambda_{1} e_{1}+\frac{\partial \mathcal{L}}{\partial e_{1}} \frac{\partial e_{1}}{\partial b_{1}}=0 \\
\frac{\partial \mathcal{L}}{\partial a_{2}}= & -\delta\left(\gamma\left(p_{2}\right) \frac{e_{1}}{\bar{e}}+1-\gamma\left(p_{2}\right)\right) g\left(p_{2}\right)+\lambda_{1} \delta\left(\gamma\left(p_{2}\right) \frac{e_{1}}{\bar{e}}+1-\gamma\left(p_{2}\right)\right) g\left(p_{2}\right) \\
& +\lambda_{2}\left(p_{2}\right)+\frac{\partial \mathcal{L}}{\partial e_{1}} \frac{\partial e_{1}}{\partial a_{2}}=0 \forall p_{2} \\
\frac{\partial \mathcal{L}}{\partial b_{2}}= & \delta\left(\gamma\left(p_{2}\right) \frac{e_{1}}{\bar{e}}+1-\gamma\left(p_{2}\right)\right)\left(\left(p_{2}-b_{2}\right) \frac{\partial e_{2}}{\partial b_{2}}-e_{2}\right) g\left(p_{2}\right) \\
& +\lambda_{1} \delta\left\{\left(\gamma\left(p_{2}\right) \frac{e_{1}}{\bar{e}}+1-\gamma\left(p_{2}\right)\right)\left(\left(b_{2}-e_{2}\right) \frac{\partial e_{2}}{\partial b_{2}}+e_{2}\right)\right\} g\left(p_{2}\right) \\
& +\lambda_{2}\left(p_{2}\right)\left(\left(b_{2}-e_{2}\right) \frac{\partial e_{2}}{\partial b_{2}}+e_{2}\right)+\frac{\partial \mathcal{L}}{\partial e_{1}} \frac{\partial e_{1}}{\partial b_{2}}=0 \quad \forall p_{2} \\
\frac{\partial \mathcal{L}}{\partial \gamma}= & \delta\left(\frac{e_{1}}{\bar{e}}-1\right)\left(p_{2} e_{2}-a_{2}-b_{2} e_{2}+C\right) g\left(p_{2}\right) \\
& +\lambda_{1} \delta\left(\frac{e_{1}}{\bar{e}}-1\right)\left(a_{2}+b_{2} e_{2}-\frac{1}{2} e_{2}^{2}-U\right) g\left(p_{2}\right) \\
& +\frac{\partial \mathcal{L}}{\partial e_{1}} \frac{\partial e_{1}}{\partial \gamma}+\mu_{1}\left(p_{2}\right)-\mu_{2}\left(p_{2}\right)=0 \quad \forall p_{2}
\end{aligned}
$$


From Eq. (10), we get:

$$
\lambda_{1}=1
$$

This result means $V^{E}=V^{U}$ (i.e., the firm guarantees utility just necessary to employ the worker). Substituting Eq. (15) and $\partial e_{1} / \partial b_{1}=1$ into Eq. (11) yields:

$$
\frac{\partial \mathcal{L}}{\partial e_{1}}=0
$$

By substituting Eq. (15) and Eq. (16) into Eq. (12), we have:

$$
\lambda_{2}\left(p_{2}\right)=0 \quad \forall p_{2}
$$

This means that the no-quit constraint for workers in Period 2 is not binding. Thus, as long as the firm solves the optimization problem presented in Eq. (9), the no-quit constraint is automatically satisfied, and workers will never quit, even without the no-quit constraint.

Proposition 1. Workers in Period 2 are always paid higher wages than they would otherwise earn because of the outside option. In other words, the following participation constraint is always satisfied:

$$
a_{2}\left(p_{2}\right)+b_{2}\left(p_{2}\right) e_{2}-\frac{1}{2} e_{2}^{2}>U \quad \forall p_{2}
$$

Proof of Proposition 1. Suppose that a firm paid just the necessary level of wages to keep workers during the second period. Then, the firm might be better off increasing $b_{2}\left(p_{2}\right)$ by a small amount and decreasing $a_{2}\left(p_{2}\right)$ by an amount so that these changes still satisfy $a_{2}\left(p_{2}\right)+b_{2}\left(p_{2}\right) e_{2}-\frac{1}{2} e_{2}^{2}=U$. This is because, if the firm paid just the necessary amount to keep workers during the second period, future wages should not affect the incentives for workers in Period 1 due to Eq. (6). Therefore, decreasing $a_{2}\left(p_{2}\right)$ would not affect efforts of workers in Period 1 but would allow the firm to increase $b_{2}$, which would enable the firm to induce greater efforts from workers in Period 2. In contrast, when the firm pays more than the necessary amount to prevent workers from quitting, decreasing $a_{2}\left(p_{2}\right)$ from the optimal level derived in this section will lower the level of workers' efforts in Period 1, which would result in a decrease in profits. Thus, the firm does not have an incentive to deviate from the optimal solutions.

The intuition for this result is that, as long as the firm pays a positive amount of wages in the second period, it is more beneficial for the firm to give workers a positive surplus that will affect their efforts in Period 1, as well. Thus, the firm pays more than necessary to keep workers during Period 2 to induce higher effort levels from workers in Period 1.

Proposition 2. Bonuses move proportionally to the output price.

Proof of Proposition 2. From the first-order conditions for $b_{2}$, we obtain $p_{2}=e_{2}^{*}$. From Eq. (7), we also know that $e_{2}^{*}=b_{2}^{*}\left(p_{2}\right)$. Combining these two equations yields:

$$
b_{2}^{*}\left(p_{2}\right)=p_{2} \quad \forall p_{2}
$$


Eq. (19) implies that the piece rate is set equal to the output price in Period 2. Thus, in equilibrium, the marginal revenue of effort from the viewpoint of a firm $\left(p_{2}\right)$, the marginal disutility of effort $\left(e_{2}^{*}\right)$, and the marginal cost of effort from the viewpoint of a firm $\left(b_{2}^{*}\left(p_{2}\right)\right)$ are set to be equal. Eq. (19) also implies that firms base their wages less on workers' performance during recessions. This is because during recessions, firms are discouraged from maintaining workers' incentives at high levels due to the low value of productivity.

Proposition 3. Layoffs occur when $p_{2}^{2} / 2-U+C<0$ is satisfied. This implies that layoffs are more likely to occur when layoff costs $C$ and the output price $p_{2}$ are low.

Proof of Proposition 3. Substituting Eq. (15), Eq. (16), $e_{2}^{*}=b_{2}^{*}\left(p_{2}\right)$, and Eq. (19) into Eq. (14), we get the following:

$$
\frac{\partial \mathcal{L}}{\partial \gamma}=\delta\left(\frac{e_{1}}{\bar{e}}-1\right)\left(p_{2}^{2} / 2-U+C\right) g\left(p_{2}\right)+\mu_{1}\left(p_{2}\right)-\mu_{2}\left(p_{2}\right)=0 \quad \forall p_{2}
$$

Since $\left(e_{1} / \bar{e}-1\right)$ in the first term in Eq. (20) is always negative by assumption, the sign of $\left\{\mu_{1}\left(p_{2}\right) \mu_{2}\left(p_{2}\right)\right\}$ depends on the sign of $p_{2}^{2} / 2-U+C$, and can be categorized as:

$$
\mu_{1}\left(p_{2}\right)-\mu_{2}\left(p_{2}\right)\left\{\begin{array}{l}
<0 \text { if } p_{2}^{2} / 2-U+C<0 \\
=0 \text { if } p_{2}^{2} / 2-U+C=0 \\
>0 \text { if } p_{2}^{2} / 2-U+C>0
\end{array}\right.
$$

Note that these two multipliers cannot be positive at the same time, since $\gamma\left(p_{2}\right)=0$ and $\gamma\left(p_{2}\right)=1$ cannot hold at the same time. Since both $\mu_{1}\left(p_{2}\right)$ and $\mu_{2}\left(p_{2}\right)$ are always non-negative, the sign of $\left\{\mu_{1}\left(p_{2}\right)-\mu_{2}\left(p_{2}\right)\right\}$ can be negative only when $\mu_{1}\left(p_{2}\right)=0$ and $\mu_{2}\left(p_{2}\right)>0$. This corresponds to the case of $\gamma^{*}\left(p_{2}\right)=1$; that is, the case in which the layoff intensity is the strongest.

The second case, $\left\{\mu_{1}\left(p_{2}\right)-\mu_{2}\left(p_{2}\right)\right\}=0$, can be true only when $\mu_{1}\left(p_{2}\right)=\mu_{2}\left(p_{2}\right)=0$ holds. In this case, $\gamma^{*}\left(p_{2}\right)$ can take any number between 0 and 1 when $p_{2}$ satisfies the condition $p_{2}^{2} / 2-U+C=0$ as an equality. With continuous $p_{2}$, this happens with zero probability. The last case $\left\{\mu_{1}\left(p_{2}\right) \mu_{2}\left(p_{2}\right)\right\}>0$ can be satisfied only when $\mu_{1}\left(p_{2}\right)>0$ and $\mu_{2}\left(p_{2}\right)=0$ correspond to the case of $\gamma^{*}\left(p_{2}\right)=0$; that is, the case of no layoffs. Mathematically, the optimal layoff decision stated above can be written as:

$$
\gamma^{*}\left(p_{2}\right) \begin{cases}=1 & \text { if } p_{2}^{2} / 2-U+C<0 \\ \in[0,1] & \text { if } p_{2}^{2} / 2-U+C=0 \\ =0 & \text { if } p_{2}^{2} / 2-U+C>0\end{cases}
$$

Thus, the case of $\gamma^{*}\left(p_{2}\right)=1$ is more likely to occur when $p$ and $C$ are low and $U$ is high.

That is, the firm's optimal layoff decision can be explained as follows: when the output price is high enough to satisfy $p_{2}>\sqrt{2(U-C)}, \gamma^{*}\left(p_{2}\right)=0$ holds; that is, no workers will be laid off. This is consistent with the findings of Bewley (1999), who showed that the majority of layoffs are implemented in response to reduced demand for labor because of a decline in product demand. The other result, which shows that higher layoff costs reduce the probability of layoffs, is intuitive and needs no explanation. 
The next proposition explains how the optimal regular pay is related to the layoff decision stated in Proposition 3.

Proposition 4. In periods where layoffs occur, the regular pay has a higher lower-bound than the regular pay in periods in which layoffs do not occur.

Proof of Proposition 4. If we substitute Eq. (19) and $e_{2}^{*}=p_{2}$ into Eq. (18), Eq. (18) becomes:

$$
a_{2}\left(p_{2}\right)>U-\frac{1}{2} p_{2}^{2}
$$

We know from Eq. (22) that $U-p_{2}^{2} / 2>C$ holds when $\gamma^{*}\left(p_{2}\right)=1$; thus, we can derive the following condition:

$$
a_{2}\left(p_{2}\right)>C \quad \forall p_{2} \text { s.t. } p_{2}<\sqrt{2(U-C)}
$$

Therefore, the lower-bound of $C$ exists for the regular pay in Period 2 when the output price of the second period is low enough for layoffs to occur. In contrast, for $p_{2}$ that satisfies $p_{2}>\sqrt{2(U-C)}, a_{2}\left(p_{2}\right)$ can be lower than $C$ because the right-hand side of Eq. (23) is lower than $C$ from Eq. (22).

Proposition 4 offers an implication for wage rigidity. Future wages scheduled to be paid in the next period during which layoffs do not occur will not affect the current efforts of workers in Period 1. This is because the workers will necessarily receive the wages without being laid off in the next period, regardless of their effort levels in Period 1. Thus, the firm cannot control workers' efforts in Period 1 by their future wages scheduled to be paid in booms, which results in lower, or at least less downwardly rigid, regular pay during booms.

In contrast, future wages scheduled to be paid in the next period during which layoffs occur affect efforts of workers in Period 1, since the workers will receive the wages only when they work hard in Period 1 and avoid being laid off. Thus, the higher the wages scheduled to be paid in regressions, the harder the workers will work. This gives the firm an incentive to pay high regular pay in periods during which layoffs occur. As a result, the regular pay of workers in Period 2 has a lower-bound, equal to the layoff costs when the output price is low enough that layoffs occur, while the regular pay can be below the layoff costs when the output price is high enough that layoffs do not occur. In this way, the downward wage rigidity in this model during recessions occurs through a channel wherein a low output price increases the probability of (performance-based) layoffs.

As confirmed in Proposition 1, if the firm must pay wages in the second period anyway, it is more beneficial for the firm to pay wages such that they affect the workers' efforts in Period 1, as well. Thus, the firm offers a surplus, paying high regular pay for periods in which layoffs occur and high bonuses for periods in which layoffs do not occur, due to the high value of productivity.

Proposition 5. Except for cases where the output price greatly declines from Period 1 to Period 2, workers' pay becomes more performance-based as their careers progress. 
Proof of Proposition 5. Given Eq. (15) and Eq. (19), Eq. (16) can be rewritten as:

$$
\frac{\partial V^{E}}{\partial e_{1}}+p_{1}-b_{1}+\delta \int_{p}\left(\gamma(p) \frac{1}{\bar{e}}\left(-a_{2}(p)+C\right)\right) d G(p)=0
$$

As shown in Eq. (22), $\gamma^{*}\left(p_{2}\right)=1$ holds for any $p_{2}$ that satisfies $p_{2}<\sqrt{2(U-C)}$, and $\gamma^{*}\left(p_{2}\right)=0$ holds for any $p_{2}$ that satisfies $p_{2}>\sqrt{2(U-C)}$. Therefore, the inside of the integral in Eq. (25) becomes zero for the realizations of $p_{2}>\sqrt{2(U-C)}$, and the second term in Eq. (25) remains only for the case in which $p_{2}<\sqrt{2(U-C)}$ :

$$
p_{1}-b_{1}+\delta \int_{p<\sqrt{2(U-C)}}\left(\frac{1}{\bar{e}}\left(-a_{2}(p)+C\right)\right) d G(p)=0
$$

Then, the conditional mean of the regular pay in Period 2, conditional on $p_{2}<$ $\sqrt{2(U-C)}$, is expressed as:

$$
E\left[a_{2}^{*}(p) / p<\sqrt{2(U-C)}\right]=\frac{\bar{e}}{\delta}\left(p_{1}-b_{1}^{*}\right) \frac{1}{\operatorname{Pr}(p<\sqrt{2(U-C)})}+C
$$

The first term in Eq. (27) shows that, to maintain the efforts of workers in Period 1, the lower the piece rate of workers in Period 1, the higher the regular pay of workers in Period 2 should be. From Eq. (24), we know that $a_{2}$ for the realizations of $p_{2}$ that satisfies $p_{2}<$ $\sqrt{2(U-C)}$ is set greater than $C$; thus, its conditional mean should also be greater than $C$. Therefore, the first term in Eq. (27) should be positive, yielding the following inequality:

$$
b_{1}^{*}<p_{1} .
$$

Proposition 5 implies that, the closer a worker's career is to its end, the less the incentive devices to induce high efforts, because workers will face less risk of future layoffs after passing many moments of layoff decisions. In the last period of the contract, what might work as an incentive device will only be the current piece rate, which results in a higher piece rate in Period 2. As a result, the piece rate paid to workers in Period 1 is set below the output price, while the piece rate paid to workers in Period 2 is set equal to the output price. Thus, if workers encounter the same output price between periods Period 1 and Period 2, they necessarily experience an increase in the piece rate as their careers progress. Except for the case in which the output price greatly declines from Period 1 to 2, workers experience a piece-rate increase as their careers progress. ${ }^{9}$

\section{Contract renewal}

Thus far, a two-period setting in which workers cannot stay in the firm for more than two periods has been assumed. In this section, this assumption will be relaxed by introduction of contract renewals.

The firm is assumed to have no information pertaining to the subsequent periods and therefore cannot decide on future contracts, i.e., it cannot offer a contract beyond Period 2. Under this setting, the firm maximizes its expected profit every two periods and renews the contract every two periods. By contrast, workers can live for multiple periods.

After the two-period contract expires, given a new contract proposed by a firm, workers initially hired at period $t$ choose their optimal effort level again. Let $V_{(t+2)}^{E *}$ be the maximized lifetime expected utility after the contract is renewed at period $t+2$; in addition, workers do not perceive that their present decisions on the level of effort affect $V_{(t+2)}^{E *}$, 
so $V_{(t+2)}^{E *}$ is taken as given in this model. The subscript variable, $t, t+1$, or $t+2$, within parentheses represents the period over the multiple-period horizon, whereas the subscript numbers 1, 2 represent the first and second periods, respectively, within the same contract period.

Similarly, the lifetime expected utility for a person unemployed in period $t$ can be written as:

$$
V_{(t)}^{U}=U+\delta\left(f V_{(t+1)}^{E o}+(1-f) V_{(t+1)}^{U}\right)
$$

where $f$ is the probability that an unemployed person finds a job. Collecting the unemployment insurance benefit for one period, $U$, the unemployed moves into employment with probability $f$; otherwise, the individual remains unemployed. I assume that in deciding the effort level, a worker believes that the contracts of other firms remain unaffected by changes in his/her own firm's contract, i.e., the worker has Nash perceptions. To incorporate this idea, here, I distinguish between $V_{(t)}^{E}$, the lifetime utility of a worker currently employed in a particular firm, and $V_{(t)}^{E o}$, the lifetime utility he/she could obtain by working in other firms.

As in the previous section, a worker's problem can be written as:

$$
\begin{aligned}
& V_{(t)}^{E}=a_{1}\left(p_{1}\right)+b_{1}\left(p_{1}\right) e_{1}-\frac{1}{2} e_{1}^{2}+ \\
& \delta \int_{p}\left\{\begin{array}{l}
\left(\gamma(p) \cdot \min \left(\frac{e_{1}}{\bar{e}}, 1\right)+1-\gamma(p)\right) \times \\
\max \left\{a_{2}(p)+b_{2}(p) e_{2}-\frac{1}{2} e_{2}^{2}+\delta V_{(t+2)}^{E *}, V_{(t+1)}^{U}\right\} \\
+\gamma(p)\left(1-\min \left(\frac{e_{1}}{\bar{e}}, 1\right)\right) V_{(t+1)}^{U}
\end{array}\right\} d G(p)
\end{aligned}
$$

With the first-order conditions solved, the effort supply functions can then be written as:

$$
\begin{aligned}
& e_{1}^{*}=b_{1}+\delta E\left[\max \left\{\frac{\gamma(p)}{\bar{e}}\left(a_{2}(p)+b_{2}(p) e_{2}-\frac{1}{2} e_{2}^{2}+\delta V_{(t+2)}^{E *}-V_{(t+1)}^{U}\right), 0\right\}\right] \\
& e_{2}^{*}=b_{2}
\end{aligned}
$$

Given these supply functions and a worker's participation constraints, the firm offers a new employee a contingent contract $X=\left(a_{1}\left(p_{1}\right), b_{1}\left(p_{1}\right), \gamma\left(p_{2}\right), a_{2}\left(p_{2}\right), b_{2}\left(p_{2}\right) ; \forall p_{2}\right)$ to maximize profit. Then, the firm's problem can be written as follows:

$$
\begin{aligned}
& \max _{X} \Pi_{(t)} \\
& \text { s.t. }\left\{\begin{array}{l}
V_{(t)}^{E} \geq V_{(t)}^{U} \\
a_{2}(p)+b_{2}(p) e_{2}-\frac{1}{2} e_{2}^{2}+\delta V_{(t+2)}^{E *} \geq V_{(t+1)}^{U} \forall p_{2} \\
e_{1}^{*}=e\left(b_{1}, \gamma, \bar{e}, a_{2}, b_{2}, V_{(t+2)}^{E *}, V_{(t+1)}^{U}, \delta\right) \\
e_{2}^{*}=e\left(b_{2}\right) \\
\gamma\left(p_{2}\right) \geq 0 \forall p_{2} \\
\gamma\left(p_{2}\right) \leq 1 \forall p_{2}
\end{array}\right.
\end{aligned}
$$

Note that the only modification that will be made to the first-order condition is the first-order condition with respect to $\gamma$. As in the previous section, with the first-order condition with respect to $a_{1}$, we obtain $\lambda_{1}=1$. With this result, the following equation holds again:

$$
V_{(t)}^{E}=V_{(t)}^{U}
$$

Then, the worker becomes aware of the relation between $V_{(t)}^{E}$ and $V_{(t)}^{U}$, which is proposed by the firm for a new contract, and expects that the same relation will be realized after 
period $t$. Indeed, provided a firm keeps maximizing its profits subject to the same constraints over time, the lifetime expected utility after being re-contracted is set equal to that of unemployment after the expiry of the two-period contract.

When we consider the fact that the above equation will also be realized for new contracts in future periods and repeat substitution over the multiple periods, $V^{U}$ can be calculated. Then, regardless of how $p$ varies, estimating $V^{E}$ and $V^{U}$ for each economic unit in future periods will be possible: Making use of Eq. (34), we can rewrite Eq. (29) as:

$$
V_{(t)}^{U}=U+\delta V_{(t+1)}^{U}
$$

If the number of periods goes to infinity, $V^{U}$ will be converged to:

$$
V^{U}=\frac{U}{1-\delta}
$$

Then, using Eq. (34) to Eq. (36), we obtain the following equation:

$$
\delta V_{(t+2)}^{E *}-V_{(t+1)}^{U}=\frac{\delta U}{1-\delta}-\frac{U}{1-\delta}=-U .
$$

The only two modifications made in this section appear in the first-order condition with respect to $\gamma$ and the effort supply function for Period 1, so these two changes become redundant in the infinite period case. Note that in a finite case, although the expression of $U$ will be changed, the main predictions about $a_{2}, b_{2}, \gamma$ in the previous section do not change.

Thus, even if we consider the contract renewal explained above, the same results can be derived, and this assures that whether we guarantee a long period for each period or not does not matter in the model. How to map the theoretical model to the real data will be addressed in Section 5.

\section{Empirical model}

This section presents an empirical strategy used to test the implications of the theoretical model. There are two steps in the evaluation. The first step is layoff regression, which tested the implications of Proposition 3. The second step is wage regression, which tested the implications of Propositions 2 and 4.

\subsection{Layoff regression}

Proposition 3 states that layoffs occur when inequality $p_{2}^{2} / 2-U+C<0$ is satisfied. This implies that layoffs are more likely to occur when the performance-based layoff costs $C$ and the output price $p$ are low. Thus, the following model is estimated:

$$
\text { Layoff }_{i t}=\eta_{0}+\eta_{1} \text { NonUnion }_{i t}+\eta_{2} \text { Price }_{i t}+X_{i t} \eta+u_{i t}
$$

where Layoff $i$ is an indicator function that equals 1 if individual $i$ is laid off in year $t$. Non-Union $_{i t}$ is a dummy variable that is 1 if the individual is a non-union worker at the beginning of year $t$, and Price $_{i t}$ represents the output price faced by the firm where individual $i$ worked at the beginning of year $t$. $X_{i t}$ represents the attributes of individual $i$ and his/her firm at the beginning of year $t$.

The union status captures the magnitude of performance-based layoff costs $C$ because these costs for unionized workers are expected to be higher than for non-union workers due to contract provisions. ${ }^{10}$ 
The expected sign for $\eta_{1}$ is positive because non-union workers are expected to have a higher probability of being laid off than are unionized workers due to their lower layoff costs. The expected sign for $\eta_{2}$ is negative because layoffs are less likely to occur when the output price is high.

\subsection{Wage regressions}

Next, a regular-pay regression is introduced to test Proposition 4, which states that the contingent regular pay becomes downwardly rigid during periods where performancebased layoffs occur. Together with Proposition 3, which states that performance-based layoffs are likely to occur during recessions, Proposition 4 has implications for the downward rigidity of regular pay during a recession.

To empirically test the theoretical implications, a finding of Bewley (1999) that $57 \%$ of non-union workers are laid off based on performance, while only $7 \%$ of union workers are laid off based on performance, is utilized. This finding means that the model setting that assumes performance-based layoffs is more applicable to non-union workers.

Thus, in the regular-pay regression, the interaction term between the "non-union worker" dummy variable and the output price is included. Including this term reveals how the coefficient of Price is different between non-union workers and unionized workers; more specifically, whether counter-cyclical movement of regular pay is more likely for non-union workers whose layoffs are more likely based on performance.

In contrast, Proposition 2 predicts that the bonus is proportional to the output price. Therefore, whether the coefficient of the output price is significantly positive is examined in the bonus-pay regression. The estimated model is:

$$
\left\{\begin{array}{l}
\text { lna }_{i t}=\alpha_{0}+\alpha_{1} \text { NonUnion }_{i t}+\alpha_{2} \text { Price }_{i t}+\alpha_{3} \text { NonUnion }_{i t} \cdot \text { Price }_{i t}+X_{i t} \alpha+u_{i t} \\
\text { ln }_{i t}=\beta_{0}+\beta_{1} \text { NonUnion }_{i t}+\beta_{2} \text { Price }_{i t}+\beta_{3} \text { NonUnion }_{i t} \cdot \text { Price }_{i t}+X_{i t} \beta+e_{i t}
\end{array}\right.
$$

where $\ln a_{i t}$ and $\ln b_{i t}$ are the logarithms of regular pay and bonus pay for individual $i$ in year $t$ respectively.

Proposition 4 predicts that $\alpha_{3}$ is significantly negative because regular pay is expected to be more counter-cyclical for non-union workers. In contrast, the sign of $\beta_{2}$ implied by Proposition 2 is significantly positive. ${ }^{11}$

Since the dependent variables in the wage regressions (regular pay and bonuses) are reported only by working people, there might be a selection bias. If there is a tendency for workers with specific unobserved characteristics to avoid layoffs during a recession, Price $_{i t}$ and the error term might be correlated. For example, if workers with very high ability are less likely to be laid off during a recession, then a lower output price would make it more likely that workers included in the sample would have high ability. ${ }^{12}$ Since such unobservable individual characteristics might be included in the error term, Price $_{i t}$ is thought to be correlated with the error term. Then, the coefficients $\alpha_{2}$ and $\beta_{2}$ could be negatively biased in the OLS. Furthermore, it is thought that this selection bias is more serious for non-union workers, since their employment is assumed less protected than that of unionized workers. This means that $\alpha_{3}$ and $\beta_{3}$ might also be biased if we use OLS. Therefore, it is necessary to use the panel data to control for workers' fixed effects. It is expected that this research problem will be resolved by introducing the fixed-effects model. 


\section{Data}

This study used Japanese panel data from the KHPS, which is conducted annually by Keio University. The KHPS data are relatively new, as data collection for the survey began in 2004. This survey is conducted in January every year and includes observations randomly chosen from almost all regions and industries in Japan. A key feature of the KHPS is that it is the first nationwide follow-up survey in Japan for individuals (4,000 households and 7,000 people) of all ages and both sexes that also captures information on education, employment, income, expenses, health, and family structure. The survey is designed to enable comparisons with major international panel surveys, such as the Panel Study of Income Dynamics (PSID) and the European Community Household Panel (ECHP) survey.

The details of the KHPS data used are as follows. Respondents for the first wave are men and women aged 20-69 as of January 31, 2004, from across Japan. The first wave (2004) included 4,005 households; the second wave (2005) included 3,314 of the 4,005 households in the first wave; the third wave (2006) included 2,887 households; and the fourth wave (2007) included 2,643. The attrition rate from the first to the fourth waves is $34 \%$.

Industry-level CPIs from the consumer price index data by the Statistics Bureau at the Ministry of Internal Affairs and Communications (Statistics Bureau, Ministry of Internal Affairs and Communications (2006)) are used as the measure of the output price. Table 1 shows the changes in annual CPI for each industry during the period 2003-2006. To avoid a potential mismatch between the CPI data and the industry categories used in the survey, the service industry and the "financing and insurance" industry are excluded from the sample. In addition, because in many cases the outputs of the mining industries are used as intermediate goods traded between firms, the price index data in the Corporate Goods Price Index are used for the mining industry (Bank of Japan 2006).

To assure that the CPI is also a good indicator of the business cycle, analyses will also be done using the gross-output deflator from Cabinet Office (2006) for a proxy of $p$ in the model. The change in the gross-output deflator is reported in Table 2; overall, the changes are similar to that of the CPIs in Table 1.

Table 1 Changes in CPI by industry

\begin{tabular}{lcccc}
\hline Industry\Year & $\mathbf{2 0 0 3}$ & $\mathbf{2 0 0 4}$ & $\mathbf{2 0 0 5}$ & $\mathbf{2 0 0 6}$ \\
\hline Agriculture & 99.6 & 103.2 & 100.0 & 102.0 \\
Communications & 108.6 & 107.3 & 100.0 & 96.4 \\
Construction & 100.6 & 100.3 & 100.0 & 100.3 \\
Electricity, Gas, Heat Supply, and Water & 99.1 & 99.2 & 100.0 & 103.6 \\
Fishery and Forestry & 99.6 & 103.2 & 100.0 & 102.0 \\
Manufacturing & 100.2 & 100.3 & 100.0 & 100.6 \\
Mining & 99.5 & 99.6 & 100.0 & 101.0 \\
Real Estate & 100.3 & 100.1 & 100.0 & 100.0 \\
Transport & 100.0 & 100.0 & 100.0 & 99.6 \\
Wholesale and Retail Trade & 100.2 & 100.3 & 100.0 & 100.6 \\
\hline
\end{tabular}

Note: The base year for CPI is 2005, and the CPI for 2005 is fixed at 100 for each industry. The CPI data was obtained from the consumer price index data by the Statistics Bureau at the Ministry of Internal Affairs and Communications (Statistics Bureau, Ministry of Internal Affairs and Communications 2006). To avoid a potential mismatch between the CPI data and the industry categories used in the survey, the service industry and the "financing and insurance" industries were excluded from the sample. The price index for the mining industry was obtained from the price index data in the Corporate Goods Price Index (Bank of Japan 2006). 
Table 2 Changes in gross-output deflator by industry

\begin{tabular}{lcccc}
\hline Industry\Year & $\mathbf{2 0 0 3}$ & $\mathbf{2 0 0 4}$ & $\mathbf{2 0 0 5}$ & $\mathbf{2 0 0 6}$ \\
\hline Agriculture & 98.9 & 103.7 & 100.0 & 101.2 \\
Communications & 100.2 & 100.0 & 100.0 & 100.3 \\
Construction & 100.2 & 100.0 & 100.0 & 100.3 \\
Electricity, Gas, Heat Supply, and Water & 102.0 & 101.6 & 100.0 & 102.1 \\
Fishery and Forestry & 98.9 & 103.7 & 100.0 & 101.2 \\
Manufacturing & 96.7 & 98.0 & 100.0 & 102.4 \\
Mining & 96.9 & 98.1 & 100.0 & 102.7 \\
Real Estate & 102.2 & 100.9 & 100.0 & 99.2 \\
Transport & 100.2 & 100.0 & 100.0 & 100.3 \\
Wholesale and Retail Trade & 99.0 & 99.6 & 100.0 & 101.1 \\
\hline
\end{tabular}

Note: The base year for the deflator is 2005 , and the deflator for 2005 is fixed at 100 for each industry. The annual gross-output deflator data is obtained from Cabinet Office (2006).

Table 3 presents a decomposition of the standard deviation of the two proxies for the output price into across-individual and within-individual components for the sample of the wage regression. During 2003-2006, the Japanese economy recovered from the recession that began in 2002, and in response to the trend, the increase in the proxy variables over the period can be observed for almost all of the industries. The gross-output deflator shows that one of the most notably affected industries by the economic recovery is manufacturing. Almost $50 \%$ of the sample is taken from the manufacturing industry; thus, the time-series variation in the proxy variable, particularly the variation in the gross-output deflator, is thought to be large enough, even within this short period. Therefore, the main analyses includes results with both of the measures.

Table 4 contains descriptive statistics for the sample of layoff regression. The samples included only individuals who are working as of January in year $t$. Those represented in the first column are divided into two groups: 1) those who left/changed employers during the year $t$ (shown in the second column) and 2) those who continued with the same employer (shown in the third column). The layoff regression determined how the employment status and the output price at the beginning of year $t$ affected the layoff probability during year $t$. Thus, Table 4 reports the characteristics of the workers (and employers) at the beginning of year $t$ and the industry-level consumer price index during January. For a robustness check, the gross-output deflator is also used for the proxy of $p$, but monthly-or quarterly-base data is not available for each industry for the gross-output deflator. Instead, the annual deflator reported in Table 2 is used in the layoff regression. Because the survey asked about a change in employer during the previous year, information on a job change

Table 3 Variance decomposition

\begin{tabular}{lccc}
\hline Proxy variables for $\boldsymbol{p}$ & Mean & Decomposition & Std. Dev. \\
\hline & 100.48 & Overall & 1.58 \\
Consumer Price Index (CPI) & & Between & 1.30 \\
& & Within & 1.13 \\
& 99.61 & & 1.64 \\
Gross-Output Deflator & & Overall & 1.26 \\
& & Between & 1.31 \\
\hline
\end{tabular}

Note: The sample is that used in the wage regression. The mean value of each proxy variable of $p$ (i.e., CPI and the gross-output deflator) and its standard error decomposed into between and within components are reported. 
Table 4 Descriptive statistics for the estimation sample of layoff regression

\begin{tabular}{|c|c|c|c|}
\hline & All & $\begin{array}{l}\text { Left employer } \\
\text { during year } t\end{array}$ & $\begin{array}{l}\text { No change } \\
\text { in employer }\end{array}$ \\
\hline \multirow[t]{2}{*}{ CPI by Industry } & 1.002 & 1.001 & 1.002 \\
\hline & $(0.009)$ & $(0.009)$ & $(0.009)$ \\
\hline \multirow[t]{2}{*}{ Output Deflator by Industry } & 1.001 & 1.001 & 1.001 \\
\hline & $(0.013)$ & $(0.012)$ & $(0.013)$ \\
\hline \multirow[t]{2}{*}{ Age } & 46.042 & 41.716 & 46.247 \\
\hline & $(11.630)$ & (11.703) & (11.588) \\
\hline \multirow[t]{2}{*}{ Tenure } & 14.016 & 6.242 & 14.385 \\
\hline & $(11.941)$ & $(9.090)$ & (11.935) \\
\hline \multirow[t]{2}{*}{ Number of Children } & 1.471 & 1.411 & 1.474 \\
\hline & $(1.094)$ & (1.133) & $(1.092)$ \\
\hline \multirow[t]{2}{*}{ Firm Size } & 186.358 & 151.284 & 188.025 \\
\hline & $(203.191)$ & $(179.084)$ & $(204.135)$ \\
\hline \multirow[t]{2}{*}{ Male } & 0.686 & 0.629 & 0.689 \\
\hline & $(0.464)$ & $(0.484)$ & $(0.463)$ \\
\hline \multirow{2}{*}{ Married } & 0.852 & 0.731 & 0.858 \\
\hline & $(0.355)$ & $(0.445)$ & $(0.349)$ \\
\hline \multirow[t]{2}{*}{ Non-unionized Worker } & 0.598 & 0.782 & 0.589 \\
\hline & $(0.490)$ & $(0.414)$ & $(0.492)$ \\
\hline \multirow[t]{2}{*}{ Change/Left Employer during Year } & 0.045 & 1.000 & 0.000 \\
\hline & $(0.208)$ & $(0.000)$ & $(0.000)$ \\
\hline \multirow[t]{2}{*}{ Laid-off } & 0.003 & 0.061 & 0.000 \\
\hline & $(0.053)$ & $(0.240)$ & $(0.000)$ \\
\hline \multirow[t]{2}{*}{ Junior High School } & 0.113 & 0.086 & 0.114 \\
\hline & $(0.316)$ & $(0.282)$ & $(0.318)$ \\
\hline \multirow[t]{2}{*}{ High School } & 0.556 & 0.594 & 0.554 \\
\hline & $(0.497)$ & $(0.492)$ & $(0.497)$ \\
\hline \multirow[t]{2}{*}{ Junior College } & 0.107 & 0.127 & 0.106 \\
\hline & $(0.309)$ & $(0.334)$ & $(0.307)$ \\
\hline \multirow[t]{2}{*}{ University } & 0.225 & 0.193 & 0.227 \\
\hline & $(0.418)$ & $(0.396)$ & $(0.419)$ \\
\hline Observations & 4342 & 197 & 4145 \\
\hline
\end{tabular}

Note: Column 1 contains the descriptive statistics for individuals who were working as of January in year $t$. Those represented in Column 1 are divided into two groups: 1 ) those who left/changed employers during year $t(\mathrm{Column} 2)$ and 2$)$ those who continued with the same employer (Column 3). "Laid off" is a dummy variable with a value of 1 if the individual was laid off during year $t$. CPI is the industry-level consumer price index during January of each year. The CPI for January 2005 was fixed at 100 for each industry. Since the gross-output deflator is not available on the monthly level, the annual gross-output deflator by industry is used in the analyses.

during year $t$ could be obtained from the survey of year $t+1$. In contrast, the characteristics of the workers (and the employers) at the beginning of year $t$ are obtained from the survey of year $t$. To utilize both, the sample is restricted to individuals who participated in the survey for at least two consecutive years. The average age of the participants is 46.0 years, and $59.8 \%$ of the sample did not belong to any labor union. Individuals who left or changed their previous employers during year $t$ comprised $5 \%$ of the sample, and $6.1 \%$ of these were laid off.

Table 5 reports the descriptive statistics for the sample of wage regressions. In these regressions, observations are restricted to individuals who earned positive values of regular pay and bonuses. Furthermore, note that in the theoretical model, the firm pays a relatively high regular pay during recessions because workers can receive the wage only 
Table 5 Descriptive statistics for the estimation sample of wage regression

\begin{tabular}{|c|c|c|c|}
\hline & All & Non-unionized worker & Unionized worker \\
\hline Regular Pay & 3796.26 & 3720.28 & 3898.05 \\
\hline (100 yen $\approx 1$ USD/month) & $(1769.03)$ & $(2065.88)$ & $(1260.85)$ \\
\hline Bonus & 12131.50 & 11308.87 & 13233.59 \\
\hline (100 yen $\approx 1$ USD/year) & $(9608.84)$ & $(10826.91)$ & $(7547.51)$ \\
\hline \multirow[t]{2}{*}{$\mathrm{CPI} / 100$} & 1.00 & 1.00 & 1.00 \\
\hline & $(0.02)$ & $(0.02)$ & $(0.02)$ \\
\hline \multirow[t]{2}{*}{ Output Deflator/100 } & 1.00 & 1.00 & 1.00 \\
\hline & $(0.02)$ & $(0.02)$ & $(0.02)$ \\
\hline \multirow[t]{2}{*}{ Age } & 48.37 & 49.49 & 46.87 \\
\hline & $(8.70)$ & (8.58) & $(8.64)$ \\
\hline \multirow[t]{2}{*}{ Tenure } & 22.75 & 22.28 & 23.38 \\
\hline & $(9.23)$ & $(9.37)$ & $(9.01)$ \\
\hline \multirow[t]{2}{*}{ Number of Children } & 1.65 & 1.57 & 1.75 \\
\hline & $(1.01)$ & $(1.04)$ & $(0.96)$ \\
\hline \multirow[t]{2}{*}{ Firm Size } & 312.06 & 236.36 & 413.48 \\
\hline & (197.52) & $(200.80)$ & $(139.01)$ \\
\hline \multirow[t]{2}{*}{ Male } & 0.86 & 0.82 & 0.91 \\
\hline & $(0.35)$ & $(0.38)$ & $(0.28)$ \\
\hline \multirow[t]{2}{*}{ Married } & 0.93 & 0.92 & 0.95 \\
\hline & $(0.25)$ & $(0.27)$ & $(0.22)$ \\
\hline \multirow[t]{2}{*}{ Non-unionized Worker } & 0.57 & 1.00 & 0.00 \\
\hline & $(0.49)$ & $(0.00)$ & $(0.00)$ \\
\hline \multirow[t]{2}{*}{ Junior High School } & 0.08 & 0.10 & 0.06 \\
\hline & $(0.28)$ & $(0.30)$ & $(0.23)$ \\
\hline \multirow[t]{2}{*}{ High School } & 0.54 & 0.46 & 0.64 \\
\hline & $(0.50)$ & $(0.50)$ & $(0.48)$ \\
\hline \multirow[t]{2}{*}{ Junior College } & 0.08 & 0.09 & 0.07 \\
\hline & $(0.28)$ & $(0.29)$ & $(0.25)$ \\
\hline \multirow[t]{2}{*}{ University } & 0.28 & 0.33 & 0.21 \\
\hline & $(0.45)$ & $(0.47)$ & $(0.41)$ \\
\hline \multirow[t]{2}{*}{ Graduate School } & 0.01 & 0.01 & 0.02 \\
\hline & $(0.10)$ & $(0.08)$ & $(0.13)$ \\
\hline Observations & 1832 & 1049 & 783 \\
\hline
\end{tabular}

Note: Observations were restricted to those who earned positive values of regular pay and bonuses. Results for workers who have worked longer than the median tenure defined for each industry $\times$ occupation category are reported to exclude the wages of newly hired workers. CPI is the annual industry-level consumer price index in Table 1. The gross-output deflator is used as the other measure of $p$, and its annual industry-level values are reported in Table 2.

when they avoid layoffs by working very hard in the previous period. Thus, in this situation, increasing workers' future wages scheduled to be paid during recessions will give workers an incentive to work hard, and this also becomes the firm's optimal strategy. In that sense, in testing the theoretical prediction on wage rigidity during recessions, the wages that workers can receive without any effort (e.g., starting regular pay) should be excluded from the wages to be analyzed because increasing such a wage does not motivate workers, and no wage rigidity arises. Thus, the empirical results for workers who have worked longer than the median tenure defined for each industry $\times$ occupation category are reported to exclude the wages of newly hired workers. This manner of calculating the median tenure reflects the fact that one period can be short or long depending on job types. 
The total annual bonus payment amounted to three times the employee's regular monthly pay. From this data, it is confirmed that most employed workers in Japan receive a substantial portion of their pay in the form of bonuses. This is consistent with the findings of previous studies that used other earning data. ${ }^{13}$ The amount paid as bonuses generally fluctuates depending on the firm's and the worker's performance, which, together with its substantial amount, suggests the importance of assuming performance-based pay rather than fixed wages, particularly for countries such as Japan.

A comparison of descriptive statistics between non-union and unionized workers shows that there is a systematic deference in the characteristics of the two groups. This implies that there should also be a difference in unobservable characteristics, which could be another reason for the differences in wage cyclicality. Thus, it is expected that not only the observable characteristics, but also time-invariant unobservable characteristics, are controlled by employing the fixed-effect model.

\section{Empirical results}

\subsection{Layoff regression results}

Table 6 presents the regression results of the layoff equation. The dependent variable is an indicator function whose value is 1 if the individual was laid off during year $t$. Individuals who are working at the beginning of year $t$ are used for the sample. In this regression, layoff experience during year $t$ is regressed on the industrial-level CPI during January, the non-union status dummy variable, and other worker characteristics at the beginning of the year. For columns 3 and 4, instead of CPI, the gross-output deflator is used for the proxy of $p$. The other worker characteristics include the male dummy variable, the education dummy variable, potential experience in years (=age-6-education years) and its square, tenure and its square, the marital status dummy variable, the number of children, the logarithm of the firm size, regional dummy variables, industry dummy variables, and occupation dummy variables.

The estimates in Table 6 show that the effect of $p$ on layoff experience is significantly negative in all columns. In other words, the data showed that layoffs are more likely to occur during periods wherein the output price is low, which is consistent with Proposition 3.

In contrast, almost all the columns suggested the significantly positive effect of the non-union worker dummy on layoff experience. This is also consistent with the prediction from Proposition 3, which stated that performance-based layoffs are more likely to occur when the costs of performance-based layoffs are low. Thus, it is expected that the theoretical predictions concerning performance-based layoffs are true in the actual data.

\subsection{Wage regression results}

In the wage regressions, the same explanatory variables as in the layoff regression are used with two exceptions. First, the interaction between non-union status and a proxy of $p$ in the wage regressions is included. Second, the CPI used in the wage regressions is the annual CPI (by industry) rather than the CPI during January used in Table 6.

Columns 1-4 in Table 7 report the results of the regular-pay regression. As discussed in Section 4, the OLS estimates could suffer from a sample selection bias. Thus, the FE estimates (and not the OLS estimates) should be considered the more reliable results. The FE estimates indicate that the coefficient of the interaction term is significantly negative, 
Table 6 Layoff regression (probit)

\begin{tabular}{|c|c|c|c|c|}
\hline \multirow{2}{*}{$\begin{array}{l}\text { Dependent variable: layoff }==1 \\
\text { Proxy of } p \text { : }\end{array}$} & (1) & (2) & (3) & (4) \\
\hline & \multicolumn{2}{|c|}{$p=\mathrm{CPI}$} & \multicolumn{2}{|c|}{$p=$ Output } \\
\hline \multirow[t]{2}{*}{$p / 100$} & -0.1265 & -0.1182 & -0.0268 & -0.0230 \\
\hline & $(0.0632)$ & $(0.0669)$ & $(0.0122)$ & $(0.0098)$ \\
\hline \multirow[t]{2}{*}{ Non-union Worker } & 0.0016 & 0.0011 & 0.0021 & 0.0014 \\
\hline & (0.0009) & $(0.0005)$ & $(0.0012)$ & $(0.0007)$ \\
\hline \multirow[t]{2}{*}{ Male } & 0.0004 & 0.0005 & 0.0005 & 0.0006 \\
\hline & $(0.0005)$ & $(0.0004)$ & $(0.0007)$ & $(0.0004)$ \\
\hline \multirow[t]{2}{*}{ High School } & -0.0013 & -0.0008 & -0.0016 & -0.0010 \\
\hline & $(0.0005)$ & $(0.0005)$ & $(0.0008)$ & $(0.0007)$ \\
\hline \multirow[t]{2}{*}{ Junior College } & -0.0008 & -0.0006 & -0.0010 & -0.0007 \\
\hline & $(0.0002)$ & $(0.0003)$ & $(0.0004)$ & $(0.0004)$ \\
\hline \multirow[t]{2}{*}{ University } & -0.0012 & -0.0008 & -0.0017 & -0.0010 \\
\hline & $(0.0003)$ & $(0.0004)$ & $(0.0006)$ & $(0.0006)$ \\
\hline \multirow[t]{2}{*}{ Experience } & -0.0000 & -0.0000 & -0.0000 & -0.0000 \\
\hline & $(0.0001)$ & $(0.0001)$ & $(0.0001)$ & $(0.0001)$ \\
\hline \multirow[t]{2}{*}{ Experience $^{2} / 100$} & 0.0000 & 0.0000 & 0.0001 & 0.0000 \\
\hline & $(0.0001)$ & $(0.0001)$ & $(0.0001)$ & $(0.0001)$ \\
\hline \multirow[t]{2}{*}{ Tenure } & -0.0000 & -0.0000 & -0.0000 & -0.0000 \\
\hline & $(0.0000)$ & $(0.0000)$ & $(0.0000)$ & $(0.0000)$ \\
\hline \multirow[t]{2}{*}{ Tenure $^{2} / 100$} & -0.0000 & -0.0000 & -0.0000 & -0.0000 \\
\hline & $(0.0001)$ & $(0.0001)$ & $(0.0001)$ & $(0.0001)$ \\
\hline \multirow[t]{2}{*}{ Married } & -0.0007 & -0.0012 & -0.0008 & -0.0013 \\
\hline & $(0.0006)$ & $(0.0015)$ & $(0.0009)$ & $(0.0016)$ \\
\hline \multirow[t]{2}{*}{ Number of Children } & -0.0000 & -0.0001 & -0.0001 & -0.0001 \\
\hline & $(0.0001)$ & $(0.0001)$ & $(0.0002)$ & $(0.0002)$ \\
\hline \multirow[t]{2}{*}{ In(Firm Size) } & -0.0002 & -0.0001 & -0.0003 & -0.0002 \\
\hline & $(0.0001)$ & $(0.0001)$ & $(0.0002)$ & $(0.0001)$ \\
\hline Regional Dummies & No & Yes & No & Yes \\
\hline Industry Dummies & No & Yes & No & Yes \\
\hline Occupation Dummies & Yes & Yes & Yes & Yes \\
\hline R-squared & 0.138 & 0.235 & 0.123 & 0.217 \\
\hline Observations & 4342 & 3164 & 4342 & 3164 \\
\hline
\end{tabular}

Note: Marginal effects evaluated at the sample mean are reported. Standard errors clustered at industry levels are in parentheses under the regression coefficients. All explanatory variables, except for the gross-output deflators, represent information reported at the beginning of year $t$. The reference group for the education dummy variables is "Junior High School." CPI is the industry-level consumer price index during January of each year.

which supports Proposition 4. In other words, the regular pay of workers in Period 2 is less responsive to changes in the output price for non-union workers. This result implies the wage rigidity of non-union workers, whose layoffs are more likely based on performance. However, with only the results in Column 2 it cannot be known whether the results in Column 2 were obtained because of the downward wage rigidity during recessions. In other words, it could also be obtained because of the upward wage rigidity during booms. To exclude the possibility of the latter rigidity, the sample in Column 3 is restricted to individuals in industries facing a decline in the CPI in each year, thereby allowing a focus on the downward wage rigidity during recessions. With this new sample, the magnitude of the coefficient of the interaction term became much larger and remained significantly negative; this implies that the significantly negative coefficient of the interaction term in Column 2 came from the downward wage rigidity during recessions, as expected. 
Table 7 Wage regression

\begin{tabular}{|c|c|c|c|c|c|c|c|}
\hline \multirow{3}{*}{ Dependent variable: } & (1) & (2) & (3) & (4) & (5) & (6) & (7) \\
\hline & \multicolumn{4}{|c|}{ Regular pay } & \multicolumn{3}{|c|}{ Bonus pay } \\
\hline & \multirow[t]{2}{*}{ OLS } & \multicolumn{3}{|c|}{$\mathrm{FE}$} & OLS & \multicolumn{2}{|c|}{$\mathrm{FE}$} \\
\hline Proxy of $p:$ & & CPI & & Output & \multicolumn{2}{|c|}{$\mathrm{CPI}$} & Output \\
\hline \multirow[t]{2}{*}{$p / 100$} & -0.792 & 0.503 & 1.806 & 0.560 & -2.349 & 0.515 & 1.593 \\
\hline & $(0.303)$ & $(0.115)$ & $(0.207)$ & $(0.253)$ & $(0.494)$ & $(0.244)$ & $(0.581)$ \\
\hline \multirow[t]{2}{*}{ Non-union } & -0.573 & 0.507 & 2.023 & 0.305 & -2.878 & -0.879 & -0.392 \\
\hline & $(0.499)$ & $(0.241)$ & $(0.357)$ & $(0.172)$ & $(0.991)$ & $(0.182)$ & $(0.704)$ \\
\hline \multirow[t]{2}{*}{$(p / 100) \times$ Non-union } & 0.553 & -0.547 & -2.043 & -0.348 & 2.755 & 0.826 & 0.339 \\
\hline & $(0.497)$ & $(0.226)$ & $(0.341)$ & $(0.154)$ & $(0.969)$ & $(0.155)$ & $(0.700)$ \\
\hline \multirow[t]{2}{*}{ Male } & 0.620 & - & - & - & 1.003 & - & - \\
\hline & $(0.030)$ & - & - & - & $(0.063)$ & - & - \\
\hline \multirow[t]{2}{*}{ High School } & 0.056 & - & - & - & 0.230 & - & - \\
\hline & $(0.047)$ & - & - & - & $(0.068)$ & - & - \\
\hline \multirow[t]{2}{*}{ Junior College } & 0.111 & - & - & - & 0.258 & - & - \\
\hline & $(0.069)$ & - & - & - & $(0.068)$ & - & - \\
\hline \multirow[t]{2}{*}{ University } & 0.126 & - & - & - & 0.297 & - & - \\
\hline & $(0.056)$ & - & - & - & $(0.026)$ & - & - \\
\hline \multirow[t]{2}{*}{ Graduate School } & 0.262 & - & - & - & 0.479 & - & - \\
\hline & $(0.059)$ & - & - & - & $(0.325)$ & - & - \\
\hline \multirow[t]{2}{*}{ Experience } & 0.021 & 0.097 & 0.099 & 0.089 & 0.020 & 0.169 & 0.144 \\
\hline & $(0.006)$ & $(0.020)$ & $(0.049)$ & $(0.023)$ & $(0.029)$ & $(0.017)$ & $(0.027)$ \\
\hline \multirow[t]{2}{*}{ Experience $^{2} / 100$} & -0.051 & -0.168 & -0.113 & -0.164 & -0.081 & -0.269 & -0.267 \\
\hline & $(0.009)$ & $(0.038)$ & $(0.095)$ & $(0.038)$ & $(0.046)$ & $(0.040)$ & $(0.036)$ \\
\hline \multirow[t]{2}{*}{ Tenure } & 0.045 & 0.040 & 0.000 & 0.046 & 0.072 & 0.024 & 0.032 \\
\hline & $(0.008)$ & $(0.042)$ & $(0.094)$ & $(0.044)$ & $(0.028)$ & $(0.101)$ & $(0.101)$ \\
\hline \multirow[t]{2}{*}{ Tenure $^{2} / 100$} & -0.058 & -0.040 & -0.082 & -0.052 & -0.067 & 0.062 & 0.058 \\
\hline & $(0.011)$ & $(0.069)$ & $(0.186)$ & $(0.067)$ & $(0.045)$ & $(0.213)$ & $(0.205)$ \\
\hline \multirow[t]{2}{*}{ Married } & 0.055 & -0.001 & -0.044 & -0.001 & 0.042 & 0.234 & 0.221 \\
\hline & $(0.049)$ & $(0.033)$ & $(0.075)$ & $(0.031)$ & $(0.105)$ & $(0.282)$ & $(0.282)$ \\
\hline \multirow[t]{2}{*}{ Number of Children } & 0.014 & -0.013 & 0.048 & -0.014 & 0.011 & -0.018 & -0.014 \\
\hline & $(0.023)$ & $(0.024)$ & $(0.026)$ & $(0.024)$ & $(0.037)$ & $(0.059)$ & $(0.059)$ \\
\hline \multirow[t]{2}{*}{ In(Firm Size) } & 0.021 & -0.004 & -0.020 & -0.004 & 0.131 & 0.060 & 0.057 \\
\hline & $(0.008)$ & $(0.010)$ & $(0.017)$ & $(0.010)$ & $(0.029)$ & $(0.022)$ & $(0.023)$ \\
\hline Test for Downward Rigidity & No & No & Yes* & No & No & No & No \\
\hline Industry Dummies & Yes & Yes & Yes & Yes & Yes & Yes & Yes \\
\hline Regional Dummies & Yes & Yes & Yes & Yes & Yes & Yes & Yes \\
\hline Occupation Dummies & Yes & Yes & Yes & Yes & Yes & Yes & Yes \\
\hline R-squared & 0.558 & 0.081 & 0.120 & 0.081 & 0.498 & 0.042 & 0.043 \\
\hline Observations & 1832 & 1832 & 963 & 1832 & 1832 & 1832 & 1832 \\
\hline
\end{tabular}

Note: *The sample in Column 3 is restricted to individuals in industries facing a decline in the CPI in each year. Standard errors clustered at industry levels are in parentheses under the regression coefficients. The reference group for the education dummy variables is "Junior High School." CPI is the annual industry-level consumer price index reported in Table 1. The gross-output deflator is the annual industry-level output deflator reported in Table 2.

Column 4 reports results using the gross-output deflators instead of the CPIs, and the result again shows a significantly negative coefficient for the interaction term.

Columns 5-7 in Table 7 present the results of the bonus-pay regression. Although the OLS estimates suggested negative coefficients for CPI, the CPI coefficient could be negatively biased in the OLS regression because of the sample selection problem as stated in Section 4. Indeed, if the FE method is employed, the effect of CPI on bonuses 
became significantly positive. Changing the price index to the gross-output deflator also returned stronger results. Thus, the results of the bonus regression are consistent with Proposition 2: the bonuses of workers in Period 2 moved in proportion to the output price.

These results from the wage regressions are consistent with Freeman and Weitzman (1987), who found that Japanese bonuses are far more procyclical than Japanese base wages. $^{14}$

\section{Conclusion}

This study presents a theoretical and empirical analysis of the effect of performancebased layoffs on wage rigidity in the context of performance pay. Given the findings of Bewley (1999) that performance-based layoffs frequently occur during a recession, especially for non-union workers, a theoretical model in which firms can decide the intensity of performance-based layoffs is constructed.

The firm's behavior guaranteeing a positive surplus, works as an incentive for workers in the first period to work hard, which is the same as the "penalty" in the usual shirking theory. However, in this paper the layoff decision has been endogenized and layoffs can occur only during recessions. Then, when we consider a contingent pay, the positive surplus is scheduled to be paid only during periods in which layoffs occur, i.e., recessions, which yields the downward rigidity of regular pay during recessions. In contrast, the performance-based component of pay, i.e., bonus, is important to induce a high effort level from workers in the current period, which implies a high bonus during booms. These results show that the two different components of pay contribute to wage rigidity in a different way.

The empirical analysis in this paper used Japanese panel data from the KHPS. All empirical results confirmed the theoretical implications.

This explanation for wage rigidity is particularly applicable for non-union workers whose layoff decisions are more likely performance-based and for countries such as Japan, where performance-based pay has been widely employed.

\section{Endnotes}

${ }^{1}$ In most economic models, firms lay workers off randomly or based on seniority. For example, Baily (1977) and Macleod et al. (1994) presented models wherein firms lay off workers randomly, while Grossman (1983) and Reagan (1992) assumed seniority-based layoffs. Nosal (1990), Strand (1991) and Strand (1992) considered both types of layoffs. Laing (1994) and Gibbons and Katz (1991) proposed signaling models wherein firms may choose to lay off workers according to their observed abilities. Ioannides and Pissarides (1983) presented a model in which a firm decides to lay off a worker based on information about an external offer to the worker.

${ }^{2}$ In Shapiro and Stiglitz (1984), the dismissal rule is given exogenously, and workers caught shirking are fired, regardless of market conditions. Sparks (1986) further developed the rule of Shapiro and Stiglitz (1984) by making workers' levels of effort and the criterion for dismissal endogenous. In Spark's model, it is assumed that workers who provide effort equal to or above the minimum standard are never dismissed, and a firm offers workers a labor contract that specifies wages and the required minimum effort standard. In equilibrium, workers' efforts are set equal to the minimum effort standard. This yields no dismissals, regardless of market conditions, as Shapiro and Stiglitz (1984) demonstrated.

${ }^{3}$ Thus, a higher value of $p_{1}$ does not lead the firm (or others) to expect a higher value of $p_{2}$. 
${ }^{4}$ Note that, because the firm can observe workers' performance and thus base wages on performance, the motivation for using the threat of layoffs as an incentive tool is different from the typical efficiency wage model. In this model, the reason for using the threat of layoffs does not stem from imperfect monitoring, but should instead be understood as the firm's strategy when both incentive tools - threat of performance-based layoffs and performance-based pay - are available.

${ }^{5}$ It is assumed that $\bar{e}$ takes a sufficiently large number (so that the probability of a worker being retained in the firm can be very close to zero when $\gamma(p)=1$ ), but it takes a finite number, so that the level $e_{1}$ does matter in the layoff decision.

${ }^{6}$ In this study, it was assumed that all workers had the same abilities and skills; thus, there was no room for the sort of inference that arises in the "career-concern" models, in which a worker's outside option in the second period depends on the market's estimate of the worker's ability. Therefore, $U$ does not depend on the level of effort in the first period, as it usually does in "career-concern" models.

${ }^{7}$ Note that the worker never has an incentive to supply an effort beyond $\bar{e}$, because this would bring about disutility without decreasing the probability of being laid off.

${ }^{8}$ Since workers in Period 2 are assumed to retire after the second period, only the current "piece rate" induces effort from workers in Period 2, as there is no threat of future layoffs. Eq. (7) explains this result.

${ }^{9}$ Simple calculations using the first-order condition for $b_{1}$ show that $b_{1}$ would become equal to $p_{1}$ if the possibility of performance-based layoffs were eliminated, that is, if $\gamma=0$ was satisfied with probability 1 . If this were to happen, the firm would not have to differentiate $b_{1}$ from $b_{2}$, since both piece rates would affect only workers' current efforts without the possibility of layoffs. In this way, when there is no possibility of performance-based layoffs, the two periods become independent of one another, and then the two-period problem becomes a per-period profit-maximization problem.

${ }^{10}$ The survey conducted by Abraham and Medoff (1984) showed that, in the U.S., approximately $78 \%$ of union groups are covered by written policies that specified seniority as the most important factor for consideration in permanent layoff decisions, while only $16 \%$ of non-union groups are covered by similar policies. The Bureau of Labor Statistics (BLS) data also revealed that in 1970-1971, over 70\% of employee groups under major union agreements in the U.S. were covered by layoff provisions that specified seniority as the most important factor for consideration in permanent layoff decisions. Given this evidence, in the empirical analysis, the union status as a proxy for layoff costs, $C$ is used.

${ }^{11}$ To use bonuses as the performance-based component of wages, it is necessary to ensure that bonuses are actually paid based on workers' current performance. This is supported by Freeman and Weitzman (1987), Ohashi (1989), and Brunello (1991), all of whom examined the Japanese bonus system. Freeman and Weitzman (1987) stated that compensating workers for their efforts is one of the main purposes of the bonus payment in Japan. Ohashi (1989) also found that bonuses are paid to compensate employees for the intensity of their work. Brunello (1991) found no statistically significant correlation between bonuses and employment levels in the automotive, steel, and electric-machinery industries in Japan, which implied that the profit-sharing aspect of the Japanese bonus system is not substantial. In particular, since the 1990s, the importance of the "pay-for-performance" aspect of the Japanese bonus system has increased. Thus, an assumption of performance pay for Japan $(w(e)=a+b e)$ is more valid theoretically than that of fixed pay $(w)$.

${ }^{12}$ This type of selection bias is the so-called counter-cyclical composition bias, although the term is usually used in the context of aggregate time-series data (Stockman (1983), Bils (1985), Solon et al. (1994), and Chang (2000)).

${ }^{13}$ It is well known that the ratio of bonuses-to-total-pay is traditionally higher in Japan than in other countries. Nakamura and Hubler (1998) showed that the ratios of bonuses to regular pay in the 1980 s are $0.317,0.121$, and 0.194 for Japan, Germany, and the U.S., 
respectively. According to Nakamura and Nakamura (1991) and Steinberg and Nakane (2011), most employed workers in Japan are paid 25-33\% of their total earnings in the form of bonus payments.

${ }^{14}$ Freeman and Weitzman (1987) also found that base wages in Japan are negatively related to employment. The results obtained from Table 7 are also consistent with this finding because base wages in this study became downwardly rigid when employment shrunk as a result of layoffs. Consequently, this implied a negative relationship between base wages and employment. Moreover, Freeman and Weitzman (1987) found that bonuses are positively related to employment. Note that, in this study, it is assumed that bonuses are paid according to workers' levels of effort. As a result, they are set equal to the output price. Thus, although the model assumed the pay-for-performance bonus model, the results did not refute the positive correlation between the amount paid in bonuses and the firms' profits (or other variables that reflected the firms' profits, such as employment). Therefore, the findings here did not contradict those of Freeman and Weitzman (1987), who also analyzed the Japanese labor market.

\title{
Competing interests
}

The IZA Journal of Labor Economics is committed to the IZA Guiding Principles of Research Integrity. The authors declare that they have observed these principles.

\author{
Authors' information \\ I received a Ph.D. in Economics from the University of Michigan in 2013. Current Position: Assistant Professor, \\ Department of Economics, Hitotsubashi University in Japan. Postal Address: 2-1, Naka, Kunitachi, Tokyo, Japan, $186-8601$. \\ Email: izumi.yokoyama@r.hit-u.ac.jp. Tel: +81-42-580-8598. Fax: +81-42-580-8598.
}

\section{Acknowledgements}

This paper was presented at the IZA Workshop on "Wage Rigidities and the Business Cycle: Causes and Consequences" on June 9-10, 2014 at IZA in Bonn. I really appreciate the feedback I received from the participants at the workshop. This research is supported by the Grant-in-Aid for Scientific Research (\#25885033, PI: Izumi Yokoyama). This paper is based on one chapter of my dissertation at the University of Michigan. I wish to thank all the members of my dissertation committee-Charles Brown, James Hines, Melvin Stephens, and Mary Corcoran—for the constant support they gave me as I worked on completing this paper. I also want to acknowledge Michael Elsby for the many comments he gave me when I developed this as my third-year paper. I also appreciate the feedback I received from the participants at Tokyo Labor Economics Workshop at the University of Tokyo, GSE-OSSIP Joint Seminar in Economics at Osaka University, and Contract Theory Workshop East (CTWE) at Hitotsubashi University. This paper was originally developed from my master's thesis, and I am also grateful to my primary advisor in my master's program at Hitotsubashi University, Isao Ohashi, and other professors who left many comments on the preliminary version of this paper-Daiji Kawaguchi, Ryo Kambayashi, and Hiroyuki Odagiri. I also thank the 21st Century Center of Excellence Program at Keio University for providing the Keio Household Panel Survey data.

Responsible editor: Pierre Cahuc

Received: 4 July 2014 Accepted: 21 August 2014

Published: 29 August 2014

References

Abraham KG, Medoff JL (1984) Length of service and layoffs in union and nonunion work groups. Ind Labor Relat Rev 38(1):87-97

Baily MN (1977) On the theory of layoffs and unemployment. Econometrica 45(5):1043-1063

Bank of Japan (2006) Corporate goods price index: Long-term time-series data. Bank of Japan, Chuo-ku, Tokyo

Bewley TF (1999) Why wages do not fall during a recession. Harvard University Press, Cambridge, MA

Bils MJ (1985) Real wages over the business cycles: evidence from panel data. J Pol Econ 93(4):666-689

Brunello G (1991) Bonuses, wages and performance in Japan: Evidence from micro data. Ricerche Economiche 45:377-395

Cabinet Office (2006) National accounts of Japan. Cabinet Office, Government of Japan, Chiyoda-ku, Tokyo

Chang Y (2000) Wages, business cycles, and comparative advantage. J Monetary Econ 46(1):143-171

Freeman RB, Weitzman ML (1987) Bonuses and employment in Japan. Journal of the Japanese and International Economies 1(2):168-194

Gibbons R, Katz LF (1991) Layoffs and lemons. J Labor Econ 9(4):351-380

Grossman GM (1983) Union wages, temporary layoffs, and seniority. Am Econ Rev 73(3):277-290

loannides YM, Pissarides CA (1983) Wages and employment with firm-specific seniority. Bell J Econ 14(2):573-580

Laing D (1994) Involuntary layoffs in a model with asymmetric information concerning worker ability. Rev Econ Stud 61(2):375-392

Lemieux T, Macleod WB, Paren D (2009) Performance pay and wage inequality. Q J Econ 124(1):1-49

Macleod WB, Malcomson JM, Gomme P (1994) Labor turnover and the natural rate of unemployment: efficiency wage vs frictional unemployment. J Labor Econ 12(2):276-315

Nakamura M, Hubler O (1998) The bonus share of flexible pay in Germany, Japan and the US: Some empirical regularities. Japan World Econ 10(2):221-232 
Nakamura M, Nakamura A (1991) Risk behavior and the determinants of bonus versus regular pay in Japan. J Japanese Int Econ 5(2):140-159

Nosal E (1990) Incomplete insurance contracts and seniority layoff rules. Economica 57(228):423-438

Ohashi I (1989) On the determinants of bonuses and basic wages in large Japanese firms. J Japanese Int Econ 3(4):451-479

Reagan PB (1992) On-the-job training, layoff by inverse seniority, and the incidence of unemployment. J Econ Business 44(4):317-324

Shapiro C, Stiglitz JE (1984) Equilibrium unemployment as a worker discipline device. Am Econ Rev 74(2):433-444

Solon G, Barsky R, Parker JA (1994) Measuring the cyclicality of real wages: How important is compositional bias? Q J Econ 109(1):587-616

Sparks R (1986) A model of involuntary unemployment and wage rigidity: Worker incentives and the threat of dismissal. J Labor Econ 4(4):560-581

Statistics Bureau, Ministry of Internal Affairs and Communications (2006) Annual report on the consumer price index. Japan Statistical Association, Shinjuku-ku, Tokyo

Steinberg C, Nakane M (2011) To fire or to hoard? explaining Japan's labor market response in the great recession IMF Working Paper WP/11/15, International Monetary Fund. https:/www.imf.org/external/pubs/ft/wp/2011/ wp1115.pdf

Stockman AC (1983) Aggregation bias and the cyclical behavior of real wages. mimeo, University of Rochester, Rochester, N.Y.

Strand J (1991) Unemployment and wages under worker moral hazard with firm-specific cycles. Int Econ Rev 32(2):601-612

Strand J (1992) Business cycles with worker moral hazard. Eur Econ Rev 36(6):1291-1303

doi:10.1186/2193-8997-3-6

Cite this article as: Yokoyama: Why do wages become more rigid during a recession than during a boom? IZA Journal of Labor Economics 2014 3:6.

\section{Submit your manuscript to a SpringerOpen ${ }^{\circ}$ journal and benefit from:}

- Convenient online submission

- Rigorous peer review

- Immediate publication on acceptance

- Open access: articles freely available online

- High visibility within the field

Retaining the copyright to your article

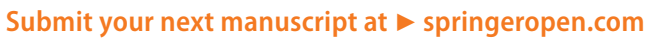

